\title{
THE EFFECT OF ADDITIVE ON CELLULOSE ACETATE MEMBRANE FROM COCONUT SAP IN DESALINATION APPLICATION
}

\author{
Senny Widyaningsih ${ }^{1 a^{*}}$, Mochamad Chasani2a, Zusfahair ${ }^{3 a}$, Muhamad Sofie \\ Khaerul Anam ${ }^{4 a}$ and Alny Nur Anisya ${ }^{5 a}$
}

aDepartment of Chemistry, Faculty of Mathematic and Natural science, Universitas Jenderal Soedirman. Jl Dr Soeparno 61 Karangwangkal , Purwokerto, INDONESIA. Email: sennysetiadi@yahoo.com ${ }^{1}$; moch.chasani@gmail.com²; zusfahair@gmail.com ${ }^{3}$; khaerul.sofi@yahoo.co.id ${ }^{4}$; anisya59@gmail.com ${ }^{5}$ Corresponding author: sennysetiadi@yahoo.com

Received: $7^{\text {th }}$ Feb $2019 \quad$ Accepted: $11^{\text {th }}$ Mar 2020

Published: $30^{\text {th }}$ Jun 2020

DOI: https://doi.org/10.22452/mjs.vol39no2.3

\begin{abstract}
The synthesis of Cellulose acetate membrane, based on coconut sap, was successful using the phase inversion method. This was then applied in the process of desalination, in order to ascertain to the performance. In addition, this is possibly affected by the introduction of additive, hence the aim of this research is to identify the possible effects. The additives used were polyethylene glycol (PEG) and formamide, and the membrane characteristics studied include flux, rejection, tensile strength, and pore size. The result showed that cellulose acetate membrane with PEG has $17.43 \mathrm{~L} /(\mathrm{m} 2 . \mathrm{h})$ of flux and $32.23 \%$ rejection, while $7.8 \mathrm{~L} /\left(\mathrm{m}^{2} . \mathrm{h}\right)$ of flux and $46 \%$ rejection were reported for formamide. Conversely, the rejection recorded without the introduction of additive was $25 \%$, hence it is assumed that additives increase membrane performance. Also, formamide was confirmed to better improve characteristic than PEG.
\end{abstract}

Keywords: cellulose acetate, coconut sap, desalination, membrane

\section{INTRODUCTION}

Desalination is a process adopted in the separation of salt from a solution. This activity is divided into two methods, which include thermal and membrane technology. In addition, about $50 \%$ is thermal based, with multistage flash (MSF), multiple-effect distillation (MED), and mechanical vapor compression (MVC) as the main processes, while membrane technology is dominated by reverse osmosis (RO). Moreover, thermal desalination procedures tend to consume larger amount of energy than RO, at the approximate equivalent of 10-15 $\mathrm{kWh} / \mathrm{m}^{3}$ and $5 \mathrm{kWh} / \mathrm{m}^{3}$ for, respectively (Ettouney \& Wilf, 2009).

There has been an upsurge in the development of membrane technology within the last decade, with the potential to replace conventional separation method (Zularrisam et al., 2007). The membrane serves as a filtration apparatus (Humplik \& Wang, 2017), due to the characteristic semipermeable film 
used to sieve substances between two phases (Galiano et al., 2018). This method is widely chosen because of high process simplicity, low energy consumption, additional chemicals are not needed, and new waste are not produced, leading to the classification as clean technology. In addition, membrane technology is effective in the removal of contaminants present in water (Yap, Ibrahim, \& Ang, 2013), although most materials used during the fabrication process include fossil based polymers (Galiano et al., 2018). This application leads to the production of pollutants known as are harmful to the environment (Laghari et al., 2016). These consequences have prompted producers to change from using fossil based polymers to biopolymer.

This comprises the use of cellulose acetate, achieved from the acetylation of cellulose from various sources, including woods (Rosnelly et $a l$. , 2013) or cotton. Furthermore, bacterial sources have also been used, which is usually obtained by the fermentation of coconut water, using Acetobacter xylinum bacteria (Cynthia L Radiman \& Sarinastiti, 2012), although the sap also has similar properties. Specifically, the water is a liquid obtained from the coconut fruit while the sap, which contains more sugar $(15.4 \%)$, is extracted from its flower (Rukmana \& Yuniarsih, 2001), hence the possibility of application as a cellulose source.

Cellulose acetate membranes are, therefore, prepared by phase inversion method, which has the following advantages over other techniques: ease of conduction, controllable pore formation, and the tendency to use with a variety of raw materials. This method involves polymer transformation from the liquid to solid phase, under control condition (Mulder, 1996), which is appropriate for the preparation of cellulose acetate membrane from coconut sap.

Several factors believed to influence the characteristics of membrane structure include the polymer type and concentration, membranemaking method, and the addition of additives (Aprilia et al., 2018). The latter was then conducted to increase the amount and size of pore, which featured the creation of larger dimensions on the sublayer of the cellulose acetate membrane. Furthermore, PEG and formamide were selected as additives for this study, as PEG possesses the capacity to increase the distribution of membrane pores and maintain resistance against external influences. Also, they are biocompatible, hydrophilic, and antifouling, with the ability to promote other characteristic. Prior studies showed the probability for possible increase in flux and decline in rejection (Mulyati et al., 2018), where another membrane prepared without PEG served as a control. Conversely, formamides have also been used because of the less volatile properties, in contrast with acetone solvents. This characteristics is responsible for the longer period of retention during the partial evaporation of membrane, which is followed by an increase in the number of pores (Vaulina et al., 2018). In addition, formamide has the advantage of elevating the flux and membrane rejection values, based on a comparison with membranes prepared without the additive, which served as a 
control. This study, therefore, investigates the effect of PEG and formamide as additive in the preparation of cellulose acetate membrane sourced from coconut sap, and the subsequent application in desalination processes.

\section{MATERIALS AND METHODS}

\subsection{Materials}

The materials used include coconut sap, Acetobacter xylinum, sugar, ammonium sulfate, glacial acetic acid, sodium hydroxide, concentrated sulfuric acid, acetic anhydride, polyethylene glycol 600, formamide, and sodium chloride. These were all obtained from Merck.

\subsection{Preparation of microbial cellulose from coconut sap}

Coconut sap microbial cellulose was conducted by boiling $5 \mathrm{~L}$ of sap, to which $500 \mathrm{~g}$ of sugar and $25 \mathrm{~g}$ of ammonium sulfate were added until completely dissolved. The resulting solution is expected to have acidity of $\mathrm{pH} 4$, followed by pouring into plastic trays, containing $400 \mathrm{ml}$ each, which was subsequently closed with sterile newspapers, and then allowed for 24 hours at room temperature. Therefore, $10 \%$ of starter bacteria Acetobacter xylinum was added and incubated at room temperature for seven days, in order to obtain microbial cellulose (Widyaningsih \& Purwati, 2013).

The product was purified by boiling for 20 minutes, and then soaked in a $1 \%$ solution of $\mathrm{NaOH}$ for 24 hours at room temperature. Therefore soaking continued with the introduction of $1 \%$ acetic acid for 24 hours, followed by washing with running water, and then the microbial cellulose was pressed and dried.

\subsection{Preparation of cellulose acetate}

The acetylation experiment involved three stages, including activation, acetylation, and hydrolysis. Specifically, activation required mixing and stirring $5 \mathrm{~g}$ of microbial cellulose and $12 \mathrm{~mL}$ of glacial acetic acid for 60 min, followed by the addition of $20 \mathrm{~mL}$ glacial acetic acid and $0.09 \mathrm{~mL}$ of concentrated sulfuric acid as a catalyst. The mixture was stirred again for 45 min, and cooled up to $16^{\circ} \mathrm{C}$ before 13.5 $\mathrm{mL}$ of acetic anhydride $98 \%$ was added. Therefore, another admixture containing $20 \mathrm{~mL}$ of glacial acetic acid and $0.6 \mathrm{~mL}$ concentrated sulfuric acid was incorporated and stirred for $20 \mathrm{~h}$ (the acetylation stage). Subsequently, the hydrolysis stage was performed by adding $30 \mathrm{~mL}$ of acetic acid $67 \%$ drop wisely within a two hr. period at $38^{\circ} \mathrm{C}$, and the reaction continued for $20 \mathrm{~h}$. The product was then poured into water, and subjected to strong agitation, followed by precipitation and washing with water until a neutral $\mathrm{pH}$ was attained, and then drying at $50^{\circ} \mathrm{C}$ (Radiman et al., 2008).

\subsection{Preparation of cellulose acetate membrane}

The membrane was formulated by phase inversion method, with casting solution composing of cellulose acetate, acetone, and additives, including PEG 
and formamide. In addition, the composition encompasses $20 \%$ cellulose acetate, $66 \%$ acetone, and $14 \%$ of PEG, which were mixed and stirred at room temperature for $24 \mathrm{~h}$ to attain homogeneity. This homogeneous polymer (dope) solution is then allowed to stand for 30 minutes, in order to remove air bubbles generated from the stirring process, which possibly cause unevenness on casting. Therefore, dope is poured into a glass plate with sides coated using a tape, to produce membranes of desired thickness, and then the printing process is conducted by pressing and pulling down to enable the formation of a thin layer.

The dope on glass plate is allowed to evaporate the solvent for 10 seconds, to ensure pore formation. These layers are then immersed in cold water at $4^{\circ} \mathrm{C}$, which acts as a coagulant, to facilitate precipitation of polymer solution (cellulose acetate) into membrane. This process is called the immersion method, characterized by the printing of polymer solution on a glass plate, which is subsequently immersed into a coagulation medium containing a non-solvent. Therefore, the acetone (solvent) diffused into the coagulant tub, while water (non-solvent) diffuse towards the membrane, in order to support the polymer formation of a solid matrix. The product becomes porous as the solvent molecules are pushed by the non-solvent, through the formation of hollows. This cellulose acetate membrane is then stored by immersion in aqueous sodium azide solution to prevent microbial growth, and similar treatment was performed using formamide as an additive. This composed of $20 \%$ cellulose acetate,
$52 \%$ acetone, and $28 \%$ formamide. Moreover, PEG was used as the polymer, in order to produce a balanced dope solution with different composition (Aprilia et al., 2018). The membrane formed was washed with deionized water to ensure the removal of all solvent and additive (Radiman et al., 2008).

\subsection{Characterization of cellulose acetate membrane}

The membrane flux and rejection were measured using dead-end test cell, under a constant pressure of $3 \mathrm{kgf} / \mathrm{cm}^{2}$, while sodium chloride solution was used as feed. In addition, the flux was evaluated every 10 minutes until a stable volume of permeate was attained (Radiman et al., 2008), while rejection measurement required the spectrophotometric determination of feed and sodium chloride permeate concentration at wavelength of $490 \mathrm{~nm}$. Therefore, the flux was evaluated using equation: $J_{v}=\mathrm{V} /($ A.t) where $\mathrm{Jv}=$ flux $\left(\mathrm{L} /\left(\mathrm{m}^{2} . \mathrm{h}\right)\right) ; \mathrm{V}=$ permeate volume; $\mathrm{A}=$ surface dimension, and $\mathrm{t}=$ time, while the rejection involved the equation: $\% \mathrm{R}$ $=\left(1-\mathrm{C}_{\mathrm{p}} / \mathrm{C}_{\mathrm{f}}\right) \times 100 \%$ with $\mathrm{R}=$ rejection; $\mathrm{Cp}=$ permeate concentration; and $\mathrm{Cf}=$ feed concentration.

The membrane morphology was observed by scanning electron microscope JSM-6510, while Autograph Shimadzu AGS-500D was used to assess the mechanical properties.

\subsection{Desalination Process}

Desalination is determined by its ability to reject salt particles, and $\mathrm{NaCl}$ solution was selected for this research, where Argentometric Mohr titration was 
used to determine the concentration. This method possibly establishes the level of $\mathrm{Cl}^{-}$and $\mathrm{Br}^{-}$under neutral or slightly alkaline conditions ( $\mathrm{pH}$ 6.5-9.0) with standard $\mathrm{AgNO}_{3}$ solutions and the addition of $\mathrm{K}_{2} \mathrm{CrO}_{4}$ as an indicator. Also, measurements are quite accurate, and sensitive at low chloride concentrations (Day \& Underwood, 1994). In addition, the membrane was cut into circular shapes with diameter of $5 \mathrm{~cm}$, and installed in the reactor, followed by the introduction of $\mathrm{NaCl}$ solution to a dead-end reactor, which was closed, and a pressure of $3 \mathrm{kgf} / \mathrm{cm}^{2}$ was subsequently applied for \pm 1.5 hours, and permeate was collected at every 10 minutes. Therefore, the salt concentration of each aliquot and concentrate is determined (Vaulina et al., 2018).

\section{RESULTS AND DISCUSSIONS}

The membrane characteristics evaluated include (1) rejection, (2) flux, which demonstrates the speed of sample transition to membrane. This is affected by the stirring process and pressure applied, and the value obtained is inversely related to the function of time, based on the-correlation shown in Figure 1. Therefore, a continuous decline in value was reported until constant (Vaulina et al., 2018), which indicates the membrane adaptation ability to the feed solution.

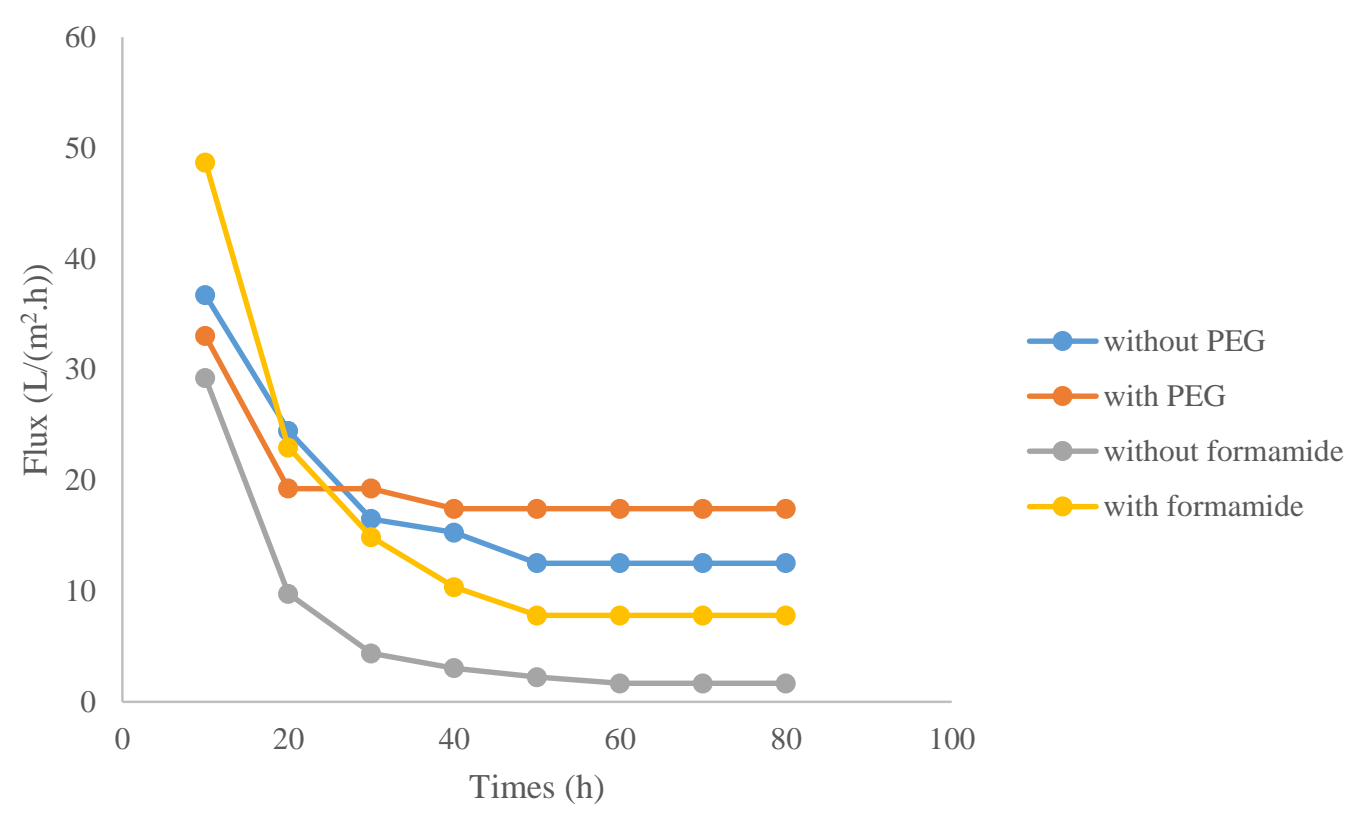

Figure 1. Flux of membrane with and without additive

Figure 1 show higher values in the flux of membrane with additives, determined by the quantity and size of pores. Also, the structure is influenced by the addition of different forms (Aprilia et al., 2018), although a comparison showed higher values with PEG over formamide. In addition, 
additives are expected to enhance pore homogeneity, increase flux value, which result from the formation of bigger pore size (Etemadi et al., 2017). This manifestation was greater in treatments with PEG than formamide, based on SEM analysis, with the flux inversely related to rejection (Mulder, 1996).

A rejection of 32.23 and $25 \%$ were measured in membrane with and without PEG, respectively. Conversely, 46 and $25 \%$ was recorded with and without the addition of formamide, which was relatively higher. The SEM analysis showed similar results, as membrane with PEG had relatively larger pore sizes. Meanwhile, rejection is an indicator of molecule retention capacity, which is related to selectivity (Mulder, 1996). This is specifically a measure of membrane ability to hold or miss a particular species, which is dependent on the interaction between membrane and dissolved particles, pore dimension, and the size of particles that pass through. Therefore, smaller pores allow the retention of more particles.

The value of tensile strength supports the results, which was higher in membrane with formamide $(9.6 \mathrm{~N})$ than PEG (7.6 N), as shown in Figure 2. Meanwhile, 6.9 $\mathrm{N}$ was recorded in the absence of any additive, because addition increases CA chain mobility, which consequently reinforces the mechanical strength. Therefore, incorporating additives results in stronger interactions between $\mathrm{CA}$ and additive molecules (Zafar et al., 2012).



Figure 2. Tensil strength of membrane

The pore size was determined through morphology analysis using scanning electron microscope (SEM), and the results are shown in Figure 3 and Figure 4. 


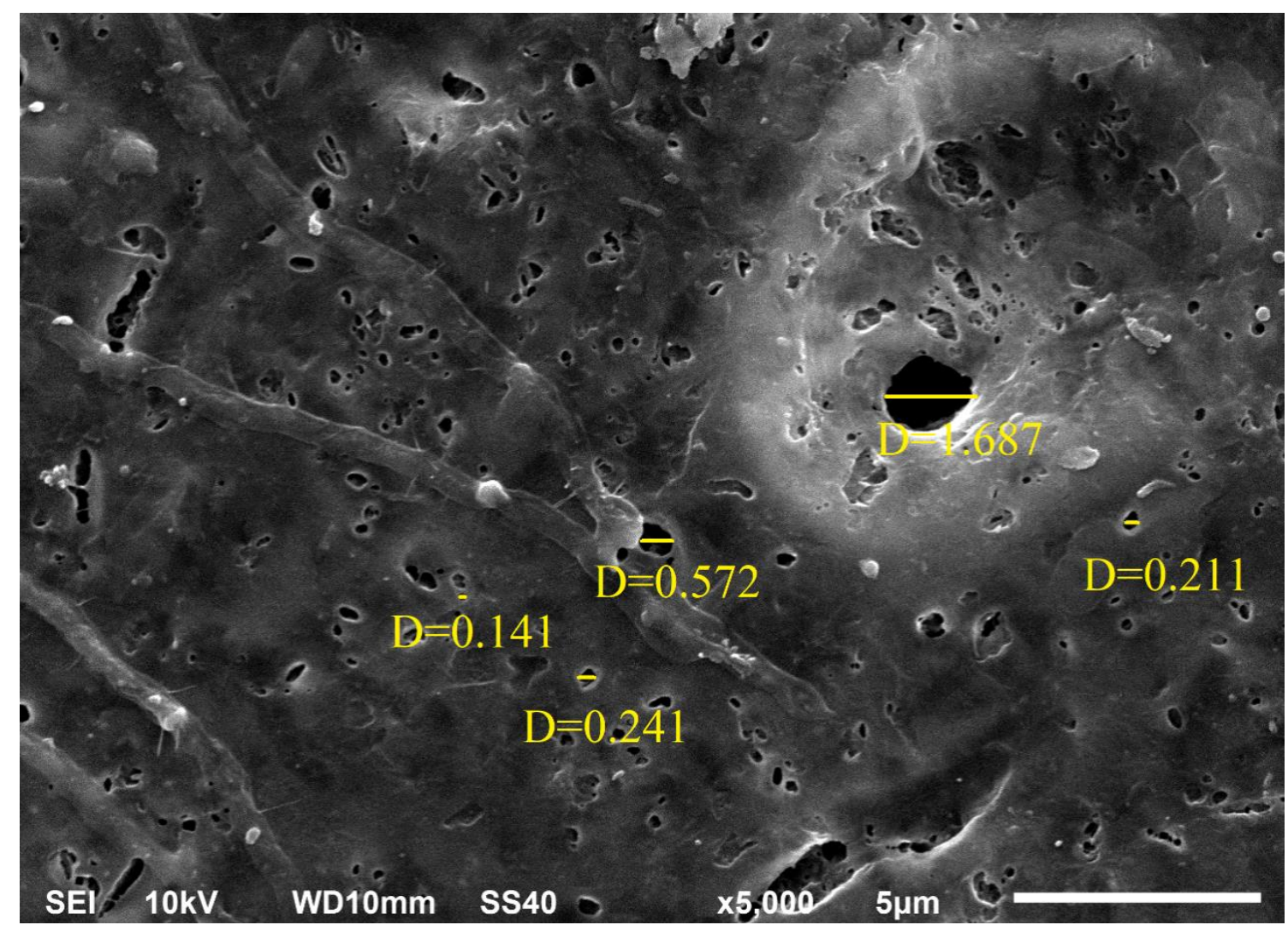

Figure 3. Membrane surface with the addition of PEG

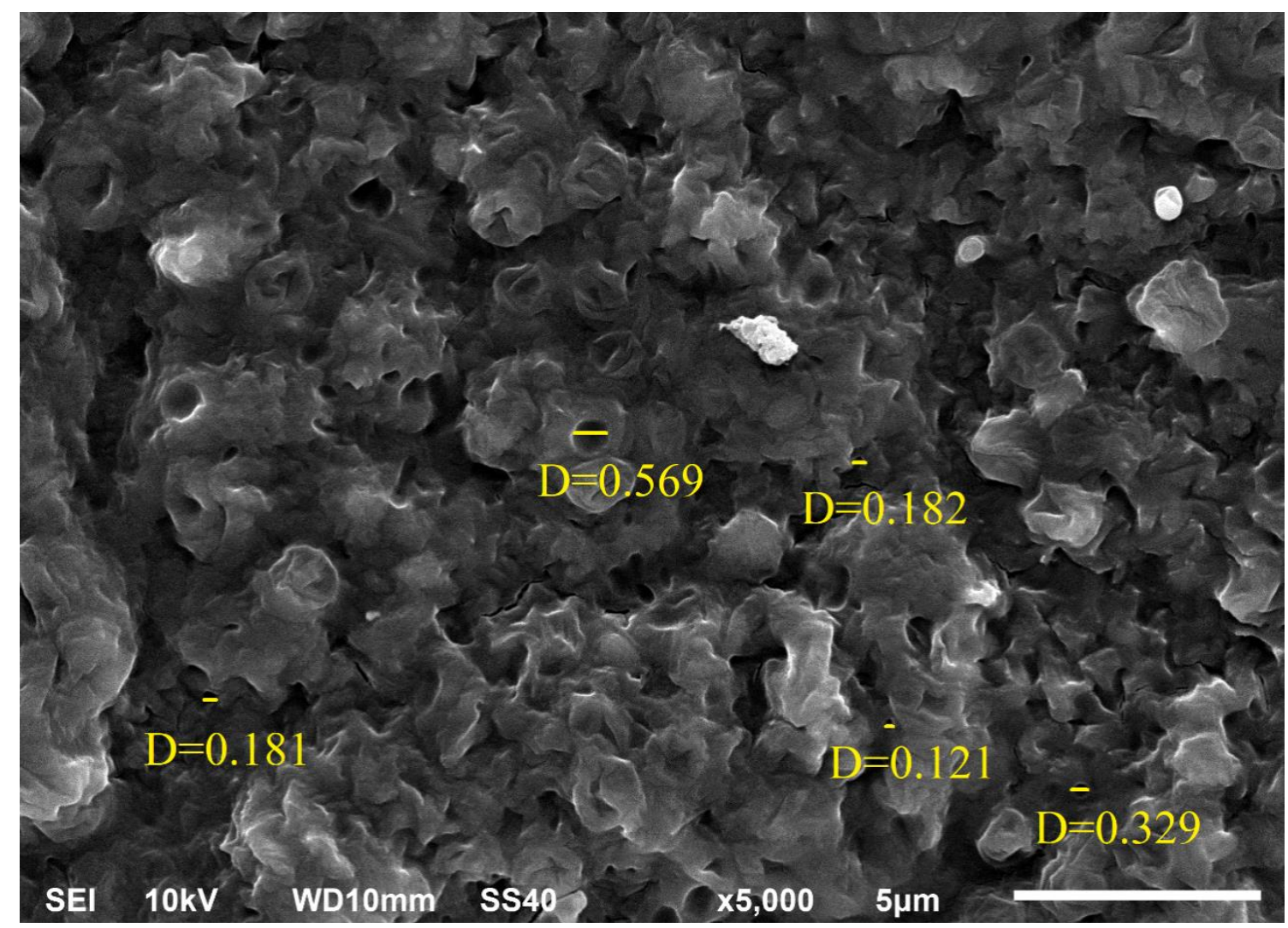

Figure 4. Membrane surface with the addition of formamide 
The addition of formamide to membrane surfaces, as shown in Figure 4 , demonstrates better pore uniformity than with PEG (Figure 3), at a range of $0.1-0.5 \mu \mathrm{m}$ and $0.5-1 \mu \mathrm{m}$, respectively. These pore characteristics influence flux and rejection, as small sizes lead to higher rejection and lower flux (Chen \& Lee, 2018).

Desalination was conducted using sodium chloride solution as feed, at a concentration of $20,883 \mathrm{ppm}$, which was reduced to 14,118 and $10,847 \mathrm{ppm}$ by membrane with PEG and formamide, respectively. Furthermore, the molecule movement through a membrane follows a diffusion mechanism, and diffusion is affected by the size and molecular weight of the solute (Mitrouli et al., 2016). However, some salt particles are small soluble substances, which facilitate the ease of transition, although this is also enhanced by the movement of solvent molecule, through coupling effect. This is particularly related to the interaction between the solute and solvent, which is strong between sodium chloride and saline water. Also, the size of $\mathrm{NaCl}$ elevates the ease of conveyance by water molecules across the membrane.

\section{CONCLUSION}

Coconut sap was used as a basic material in the production of cellulose acetate membranes, through a fermentation process, which causes changes and the subsequent synthesis from bacterial cellulose. Furthermore, the addition of additive leads to better product performance, although formamide provides better characteristic than PEG. This was due to the more effective salinity reduction ability.

\section{ACKNOWLEDGEMENT}

The authors are grateful to the Ministry of Research, Technology and Higher Education, Indonesia, and Jenderal Soedirman University, through the Research Grant of "Riset Peningkatan Kompeternsi" Contract Number: 2301/UN/23.14/PN/2017.

\section{REFERENCES}

Aprilia, N. A. S., Fauzi, Azmi, N., Najwan, N., \& Amin, A. (2018). Performance of cellulose acetate membrane with different additives for palm oil mill effluent (POME) liquid waste treatment. IOP Conference Series: Materials Science and Engineering, 334(1). https://doi.org/10.1088/1757899X/334/1/012024

Chen, G. J., \& Lee, D. J. (2018). Synthesis of asymmetrical cellulose acetate/cellulose triacetate forward osmosis membrane: Optimization. Journal of the Taiwan Institute of Chemical Engineers, (xxxx). https://doi.org/10.1016/j.jtice.2018. 10.031

Day, R. A., \& Underwood, A. L. (1994). Analisa Kimia Kuantitatif. Erlangga.

Etemadi, H., Yegani, R., \& Babaeipour, V. (2017). Performance evaluation and antifouling analyses of cellulose acetate/nanodiamond nanocomposite membranes in water treatment. Journal of Applied Polymer Science, 134(21), 1-14. https://doi.org/10.1002/app.44873

Ettouney, H., \& Wilf, M. (2009). Conventional Thermal Process. Seawater Desalination: 
Conventional and Renewable Energy

Processes. https://doi.org/10.1007/978-3-64201150-4

Galiano, F., Briceño, K., Marino, T., Molino, A., Christensen, K. V., \& Figoli, A. (2018). Advances in biopolymer-based membrane preparation and applications. Journal of Membrane Science, 564(May), 562-586. https://doi.org/10.1016/j.memsci.2 018.07.059

Humplik, T., \& Wang, E. (2017). Desalinating sea water: towards novel desalination membranes with enhanced performance. Membrane Technology, 2017(3), 10-11. https://doi.org/10.1016/S09582118(17)30058-7

Laghari, S. M., Isa, M. H., \& Laghari, A. J. (2016). Delignification of palm fiber by microwave assisted chemical pretreatment for improving energy efficiency. Malaysian Journal of Science, 35(1), 8-14.

Mitrouli, S. T., Kostoglou, M., \& Karabelas, A. J. (2016). Calcium carbonate scaling of desalination membranes: Assessment of scaling parameters from dead-end filtration experiments. Journal of Membrane Science, 510, 293-305. https://doi.org/10.1016/j.memsci.2 016.02.061

Mulder. (1996). Basic Principles of Membrane Technology (first edit). Dordrecht: Kluwer Academic.
Mulyati, S., Aprilia, S., Safiah, Syawaliah, Armando, M. A., \& Mawardi, H. (2018). The effect of poly ethylene glycol additive on the characteristics and performance of cellulose acetate ultrafiltration membrane for removal of $\mathrm{Cr}$ (III) from aqueous solution. IOP Conference Series: Materials Science and Engineering, 352(1). https://doi.org/10.1088/1757$899 X / 352 / 1 / 012051$

Radiman, C. L., Widyaningsih, S., \& Sugesty, S. (2008). New applications of kenaf (Hibiscus cannabinus L.) as microfiltration membranes. Journal of Membrane Science, 315(1-2), 141-146. https://doi.org/10.1016/j.memsci.2 008.02.012

Radiman, Cynthia L, \& Sarinastiti, A. (2012). Cellulosic Materials As Polymer Electrolyte. Jurnal Selulosa, 2(2), 46-52.

Rosnelly, C. M., Darmadi, \& Sofyana. (2013). Effect of Dope Solution Temperature on Characteristic and Performance of Cellulose Diacetate Membrane Based on Cellulose of Sengon Wood ( Paraserianthes falcataria $\mathrm{sp}$ ). In Journal on Advanced Science Engineering Information Technology, 3(2), 1518.

https://doi.org/10.1016/j.biocon.20 17.10.008

Rukmana, R., \& Yuniarsih, Y. (2001). Membuat Kecap: Tempe Busuk, Nira, Air Kelapa (first edit). Yogyakarta: Kanisius. 
Vaulina, E., Widyaningsih, S., Kartika, D., \& Romdoni, M. P. (2018). The Effect of Cellulose Acetate Concentration from Coconut Nira on Ultrafiltration Membrane Characters. IOP Conference Series: Materials Science and Engineering, 349(1). https://doi.org/10.1088/1757$899 X / 349 / 1 / 012020$

Widyaningsih, S., \& Purwati, P. (2013). Pemanfaatan Membran Nata De Coco Sebagai Media Filtrasi Untuk Rekoveriminyak Jelantah. Molekul, $\quad 8(1), \quad 20$. https://doi.org/10.20884/1.jm.201 3.8.1.122

Yap, P. S., Ibrahim, S., \& Ang, K. B. (2013). TREATMENT OF RUBBER GLOVE WASTEWATER BY ULTRAFILTRATION. Malaysian Journal of Science, 32(1), 61-65.
Zafar, M., Ali, M., Maqsood, S., Jamil, T., Taqi, M., \& Butt, Z. (2012). Effect of additives on the properties and performance of cellulose acetate derivative membranes in the separation of isopropanol / water mixtures. Desalination, 285, 359365.

https://doi.org/10.1016/j.desal.201 1.10 .027

Zularrisam, A. ., Ismail, A. ., \& Salim, M. . (2007). Ultrafiltartion of Natural Organic Matter (NOM): Effect of NOM Characteristic on Membrane Rejection Mechanisms in Drinking Water Process. Malaysian Journal of Science, 26(1), 97-107. 